\title{
Are There Optimal Forms of Public-Private Partnerships?
}

\author{
Yi Karnes \\ Department of Management \\ California State University, East Bay
}

\begin{abstract}
Many emerging economies have launched ambitious efforts to privatize state-owned enterprises (SOEs). However, not all privatization entails complete ownership and control transfer from public to private hands. In this study, we recognize different forms of public-private partnerships in investment projects in emerging economies. We conceptualize these organization forms as different ownership and control by SOEs and private entities. Integrating transaction cost economics (TCE), agency theory, and institution-based view; we propose that public-private partnership forms are interdependent with characteristics of private entities and institutional environments. We find that there are optimal forms of partnerships that benefit the performance of public-private investments.
\end{abstract}

Keywords: transaction cost economics, agency theory, governance structure

\section{Introduction}

Privatization connotes the transfer of assets, functions, and responsibilities from the state to private hands. However, not all privatization entails complete ownership transfer from public to private entities. In many industries, privatization has often been labeled "public-private partnerships" to indicate any form of private participation in government owned enterprise or operations (Doh, 2000; Filatotchev, Stephan, \& Jindra, 2008). This trend has been remarkably pronounced in infrastructure industries such as telecommunications, electricity, water, and transportation, which constitute a majority of privatizations because state-owned enterprises (SOEs) had monopolies in these industries for a long time (Henisz, Zelner, \& Guillen, 2005).

Research on privatization in emerging economies has investigated the causes and trends of privatization (De Castro \& Uhlenbruck, 1997; Henisz et al., 2005; Ramamurti, 2003). Nevertheless, most studies tend to view privatization as a homogenous and simplistic transfer of assets from public ownership to private ownership. Around the world, it turns out that governments and SOEs continue to play a major role in many "privatized" firms (Bortolotti \& Faccio, 2009; Bruton, Peng, Ahlstrom, Stan, \& Xu, 2015). As a result, previous research tends to overlook the diversity of different governance structures in privatized projects, which is a major source of variation in the observed results of privatization (Zahra, Ireland, Gutierrez, \& Hitt, 2000). Endeavoring to acknowledge such diversity in privatization, our study explores different 


\section{OPTIMAL FORMS OF PUBLIC-PRIVATE PARTERNSHIPS?}

ownership structures and transactions between SOEs and private entities, manifested in different forms of public-private partnerships.

In reality, some public-private partnerships are structured in a complex manner. In emerging economies, particularly in politically sensitive infrastructure industries, straightforward private acquisition of SOEs' assets is not a predominant form of privatization whereas publicprivate partnership is more widely adopted. Conceptually, we recognize three forms of publicprivate partnership that represent three governance structures. The first is management contract, in which the SOE retains its ownership rights, while releasing management control to private entities. The second form is acquisition - private entities acquire ownership and control rights of the SOE through an asset sale, public offering, or mass privatization program. This is the most straightforward and thus most widely used conceptualization of "privatization." The third form is greenfield, in which a private entity or a public-private joint venture builds and operates a new facility, obtaining both ownership and control rights of the project.

Our study contributes to the existing literature in three ways. First, drawing from transaction cost economics (TCE), we suggest that different forms of public-private partnership projects can be viewed as having different levels of transactions between SOEs and private entities. Second, we apply agency theory and explicitly analyze the principal-agent relationship between SOEs (representing the government) and private entities in public-private partnership projects. We further integrate institution-based view with TCE and agency theory and explore how private investors evaluate the form of public-private partnerships based on the institutional environments.

Governance structures affect the performance of public-private partnership projects by influencing the relationship between SOEs and private entities. Two research questions thus arise: (1) What drives the choice of certain forms of public-private partnerships? (2) Are there optimal forms of public-private partnerships that enhance the performance of the projects? The purpose of this article, therefore, is to address these two important but previously less explored questions.

\section{Literature Review}

According to agency theory, SOEs are characterized by agency conflicts that result in inefficiency (Cuervo-Cazurra, Inkpen, Musacchio, \& Ramaswamy, 2014; La Porta \& Lopez-deSilanes, 1999). The SOE managers lack incentives to improve firm performance and the government's political agenda results in excessive employment and poor strategic decisions (Lin \& Germain, 2003; Shleifer \& Vishny, 1994). From the agency theory perspective, various mechanisms of governance control may be classified as internal and external (Walsh \& Seward, 1990), both of which act to increase quality of firm performance (Kalodimos, 2017). Internal corporate governance includes ownership and control mechanisms inside the firm. A main change introduced by privatization in emerging economies is property rights. Property rights refer to the locus of authority for making strategic choices (Jensen \& Meckling, 1976) and also emphasize on the incentives for principals to monitor agents (Boycko, Shleifer, \& Vishny, 1996). Different forms of public-private partnership determine how the principal-agent relationship is defined and how much ownership or control is transferred from SOEs to private entities. These 
different organizational forms must tradeoff between coordination benefits and their associated costs in terms of renegotiation (Poitevin, 1995).

The first form of public-private partnership is management contract. In a management contract, a private entity (the agent) takes over the management part of an SOE (the principal) while ownership remains with the state and investment decisions are made by the SOE. Through the management contract, the state and the private entity resolve transaction disputes within the SOE. The SOE and private entities learn a great deal about which investment terms and conditions may be most effective, efficient, and viable in economic, political, and social terms (Doh, Teegen, \& Mudambi, 2004; Jiang, Peng, Yang, \& Mutlu, 2015) and adapt to each other's decision making and management style in a coordinated manner.

The second form of public-private partnership is acquisition. When SOEs' property is acquired by a private entity, the state relinquishes both ownership and control rights in the assets, and the private entity becomes the principal of the privatized facility. However, newly privatized firms in emerging economies often find it necessary to seek financial, technological, and managerial resources and capabilities from more richly endowed firms (Hitt, Dacin, Levitas, Arregle, \& Borza, 2000), which may be the former SOEs. Thus, SOE's assets are often divested in stages, resulting in transactions between the private entity and the rest of the SOE after acquisition.

The third form of public-private partnership is greenfield investment. In this type of privatization, the private entities invest in a greenfield facility, in which they have both ownership claims and the control rights of the project. Different from management contracts, greenfield investments avoid political interference from SOEs with clearly defined property rights - the private entities being the principal. Also different from acquisition projects, greenfield projects have least transactions with SOEs, and thus could be regarded as the type of privatization most free of control from SOEs.

Overall, we argue that management contract results in high level of transactions between SOEs and private entities, acquisition entails some transactions, and greenfield essentially has least transactions between the two sides (Figure 1). We contend that different levels of transactions have major implications on the choice of public-private partnership forms and consequentially the performance of the projects - a perspective developed next. 
OPTIMAL FORMS OF PUBLIC-PRIVATE PARTERNSHIPS?

\section{Figure 1}

Transactions between private entities and SOEs in public-private partnership projects

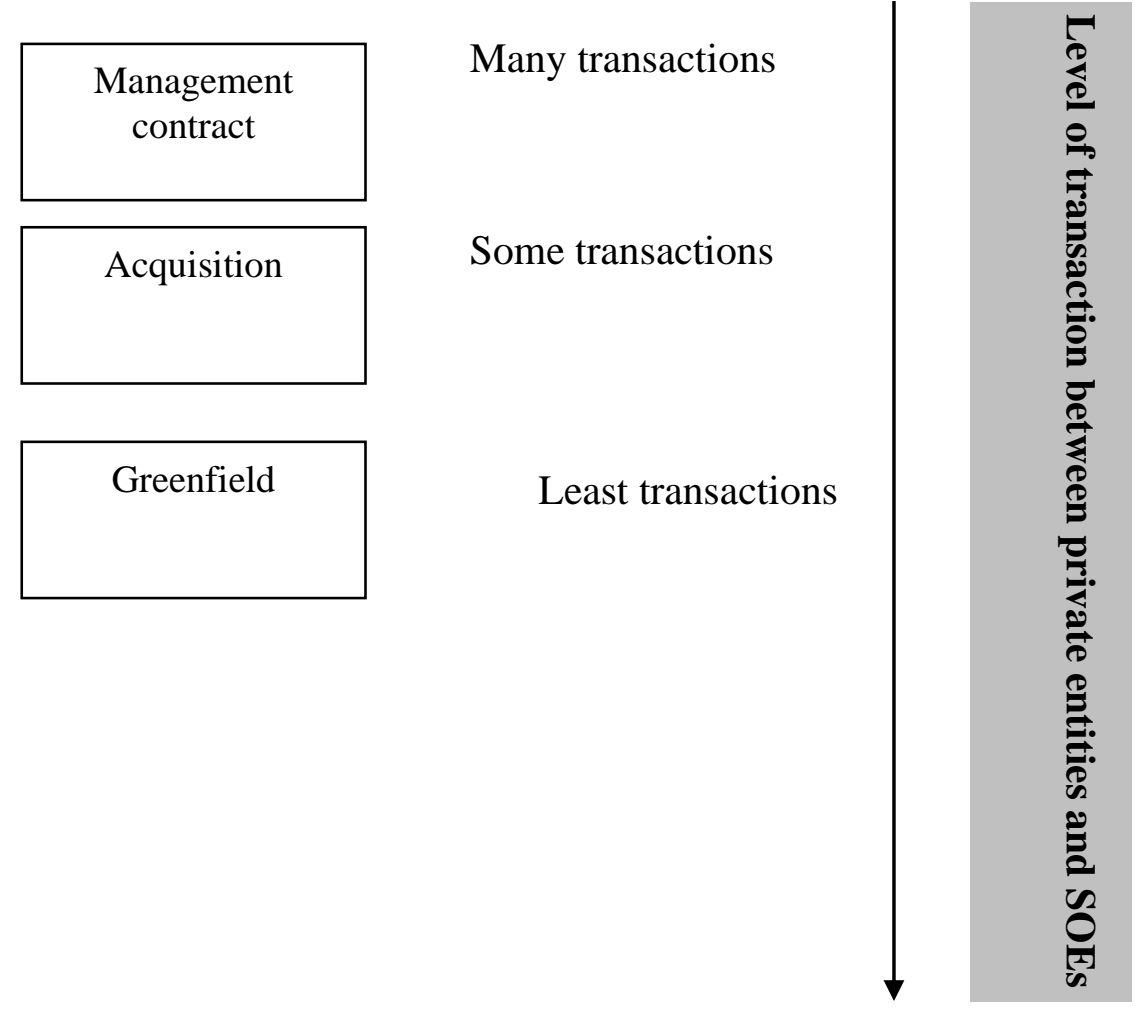

\section{Optimal forms of public-private partnership}

Research has explored optimal organizational forms due to different incentives of the principal and agents (Shin, 2017). In the SOE-private entities relationship, while SOEs are not disciplined by the fear of bankruptcy because SOEs have access to government bailouts, private entities, however, face threats of failure. If the privatization project fails, assets invested by the private entity can not be redeployed to alternative uses without sacrifice of productive value (Henisz \& Zelner, 2001). Thus, private entities have every incentive to make strategic choices that ensure the survival of the projects. One consideration of choosing the optimal forms of public-private partnership is the institutional environment - a basic proposition of institutionbased view (Hoskisson, Eden, Lau, \& Wright, 2000; Peng, Wang, \& Jiang, 2008).

\section{Political stability in the institutional environment}

Integrating TCE, agency theory and institution-based view (Aguilera \& Jackson, 2003; Martinez \& Dacin, 1999; Meyer \& Peng, 2016), research has focused on the diversity of governance structures across institutional environments. Studies show that governance structures vary across countries with different investor protections (Boubakri, Cosset, \& Guedhami, 2005; 
Dyck \& Zingales, 2004; Megginson, Nash, Netter, \& Poulsen, 2004). Institutional environments promote economic exchange by creating order and reducing uncertainty (North, 1990; Williamson, 1985). Institutional environments moderate the impact of governance on organizational performance (Aguilera, Filatotchev, Gospel, \& Jackson, 2008) and political stability is a crucial consideration of governance structures (Aguilera \& Jackson, 2003). Political stability lends credibility and ability of the government to implement economic reforms, protects private investors from future policy reversals (Perotti \& van Oijen, 2001), and provides external mechanisms to postprivatization corporate governance. Firm performance often depends on the efficiency of a bundle of governance mechanisms, including external mechanisms and internal mechanisms (Aguilera, Desender, Bednar, \& Lee, 2015; Rediker \& Seth, 1995). An optimal form of public-private partnership, as an internal governance mechanism, is crucial to complement an external institutional environment.

Private entities do not necessarily lead private participation projects to smoothly adapt to uncertain institutional environments. Insights from agency theory suggest that principal-agent problem arises when the owner of the firm (the principal) and the manager of the firm (the agent) are separated. When private entities participate in a privatization project through a management contract, they presume the principal-agent relationship with the SOE and expect a high level of transactions with the SOE. A politically unstable environment, with greater risks in transactions between private entities and the SOE, and greater information processing requirements, would not be complementary to the internal governance structure of management contract.

Privatization through greenfield or acquisition has much less transaction with the SOE, creating the possibility of governance by private actors (Spicer, McDermott, \& Kogut, 2000), thus is less subject to uncertainties in the institutional environment. When private entities choose to participate in a management contract, information exchange and feedback with the SOE is tremendous, rendering the performance of the project dependent on the country's political stability.

By including private entities in the management process, the public-private partnership of management contract also helps SOEs learn how to interact with a market-based entity and institutionalize some market-based, efficiency-driven logic within its managerial ranks (Johnson, Smith, \& Coding, 2000). Therefore, the internal governance structure of a management contract complements the external governance mechanism of political stability, presenting an optimal form of pubic-private partnership in politically stable institutional environments.

Hypothesis 1a: Public-private partnerships in a more politically stable country are more likely to take the form of management contract as opposed to greenfield or acquisition.

Hypothesis 1b: A more politically stable country has more favorable effects on the performance of management contract than on the performance of greenfield or acquisition projects. 


\section{Foreign investment}

Agency theory contends that foreign investors are the source of better governance due to strict control of managers' activities (Boycko et al., 1996; Dyck, 2001). Research results on foreign investment performance in privatization, however, are mixed. Some studies find that foreign investors do not have better firm performance than domestic investors in newly privatized firms (Cull, Matesova, \& Shirley, 2002) whereas others determine that foreign ownership is associated with greater performance improvement than domestic ownership (Djankov, 2014). Privatization opens the opportunity to foreign investors to participate in SOEs. We may not fully understand the relationship between performance and foreign investors without exploring the chosen form of public-private partnership of foreign investors. Entering into foreign markets through participating in an acquisition deal compensates foreign investors' lack of information through obtaining managers familiar with the local market and gaining access to a pool of suppliers and customers in the business network, which would have cost a lot more if they try to set up the network from scratch in a greenfield investment (Lebedev, Peng, Xie, \& Stevens, 2015; Peng \& Jiang, 2005). Thus, foreign investors may favor acquisition over greenfield investment in a privatization project, which contributes to the performance of the project.

From the information-processing perspective, foreign investors face the complexity of transactions after entering emerging economies (Hoskisson et al., 2000). TCE recognizes that transaction costs increase when foreign investors negotiate with government authorities (Meyer, Estrin, Bhaumik, \& Peng, 2009). An optimal public-private partnership may help foreign investors reduce the complexity of information processing and high transaction costs. Compared with management contract, an acquisition grants foreign investors the ownership and control of the acquired assets, thus reduces transactions with SOEs. Being the principal of the acquired entity, foreign investors have positive effects on risk-taking (Filatotchev et al., 2008) and play an important governance role. Therefore, the governance structure of an acquisition presents an optimal form of pubic-private partnership in foreign invested privatization projects.

Hypothesis 2a: Compared with domestic investors, foreign investors are more likely to choose acquisition over management contract or greenfield in public-private partnerships.

Hypothesis 2b: Compared with domestic investors, foreign investors have more favorable effects on the performance of acquisitions than on the performance of management contract or greenfield investments.

\section{Level of private participation}

The essential element of the decision as to what type of transaction will be more efficient is the extent to which the parties invest in durable, nonmarketable assets (Williamson \& Ouchi, 1981). Without uncertainty, even highly specialized assets may be protected contractually (Mahoney, 1992). However, emerging economies tend to have a more erratic formal institutional environment (Wright, Filatotchev, Hoskisson, \& Peng, 2005), more restricted product markets (Banalieva, 2014), and weaker formal regulatory regimes (La Porta, Lopez-de-Silanes, Shleifer, \& Vishny, 1998). There are "rational economic reasons" (Williamson, 1985: P.51) for private 
OPTIMAL FORMS OF PUBLIC-PRIVATE PARTERNSHIPS?

entities to choose the means of ownership and control that minimize uncertainty and opportunism.

\section{Figure 2}

\section{Research model}

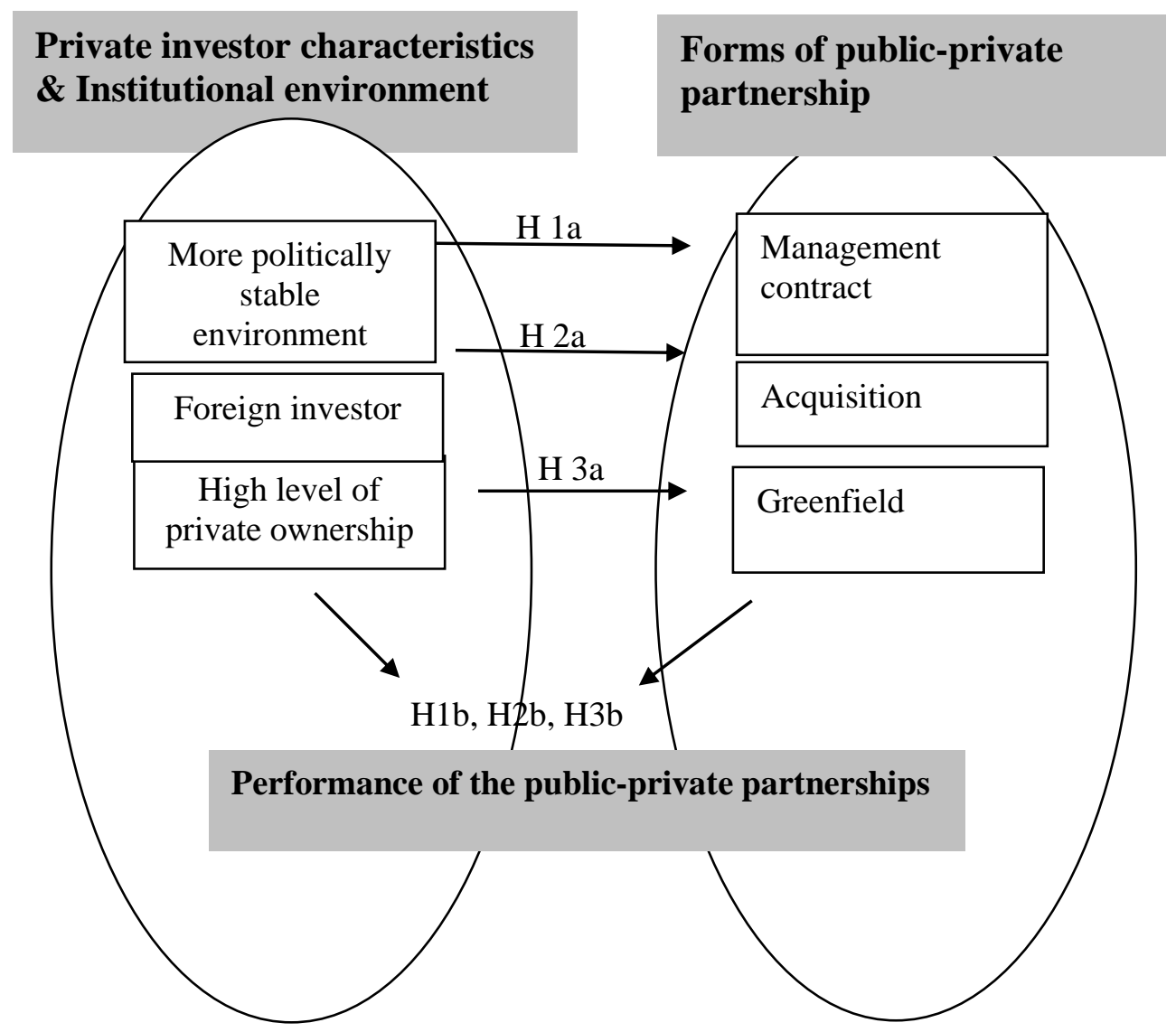

When private entities make high level of investments, the scope of asset specific operations requires them to seize competitive opportunities and make profits out of their investments. Transaction partners with a high level of investments may tend to choose an investment with less transaction with another party (Kogut \& Zander, 1993). In privatization projects, higher level of private participation renders private entities subject to costly haggling and maladaptiveness from the transaction partner (Williamson, 1985). Haggling can raise costs, delay procedures, or even kill the project. Before privatization, the government has to satisfy multiple political claims in managing SOEs, which may result in significant deviation from market-based efficiency (Zahra et al., 2000). At the onset of privatization, this template may still be deeply embedded and the state may retain many features conflicting with the management of a market system (Makhija, 2004). Moreover, researchers on privatization note that deals in emerging economies are likely to include post-privatization conditions such as some form of government interference (De Castro \& Uhlenbruck, 1997). In addition to incentive conflicts, 
failures of transaction may arise because SOEs and private entities read and react to signals differently (Gulati, Lawrence, \& Puranam, 2005; Williamson, 1991). Protecting themselves against being held up, private entities with a high level of private participation may favor an arrangement that minimizes transactions with SOEs, an optimal form of pubic-private partnership represented by greenfield. Therefore:

Hypothesis 3a: Public-private partnerships with higher level of private investments are more likely to take the form of greenfield as opposed to management contract or acquisition.

Hypothesis 3b: Higher level of private investments has more favorable effects on the performance of greenfield projects than on the performance of management contract or acquisition projects.

\section{Data}

\section{Methodology}

We acquired a data set of projects in emerging economies drawn from the World Bank's Private Participation in Infrastructure (PPI) Database. After further excluding projects with missing data, we have 7,610 projects from 113 emerging economies in the data set during the period 1990-2009 (inclusive).

Public-private partnership is classified into four categories in the original database: management contracts, concession contracts, greenfield and divestiture. Projects under managerial and concession contracts are coded as having a management contract form. Projects under divestiture are coded as acquisitions. A total of 1,848 out of 7,610 projects are of this type. There are 4,516 greenfield projects and 1,246 acquisition projects.

\section{Variables}

\section{Performance}

Projects status is identified as (1) under construction, (2) operational, (3) concluded, (4) canceled, and (5) distressed. We code projects under construction, operational, and concluded as "survived projects." In distressed projects, the government or the operator has either requested contract termination or are in international arbitration. Distressed projects and canceled projects are considered as "failed projects". A total of 529 out of the 7,610 projects failed, and 7,081 projects survived as of the time data were collected. The dependent variable: performance of the public-private partnership is coded 1 if the project is identified as survived and 0 if the project is cancelled or distressed.

\section{Political stability}

Henisz's Political constraint index is used to measure political stability in an institutional environment. The index is scaled 0 to 1 with 0 indicating most hazardous political environment and 1 indicating extensive checks and balances in the institution. The projects are matched with the index's country and year. 


\section{OPTIMAL FORMS OF PUBLIC-PRIVATE PARTERNSHIPS?}

\section{Foreign investment}

Foreign investment is coded 1 when there are no domestic private investors - that is to say, all investors are from foreign countries.

\section{Level of private participation}

In management contract, the level of private participation is measured as the percentage of the former SOE's equity controlled by the private entity. In greenfield and acquisition projects, the level of private participation is measured as the percentage of the projects owned by private entities.

\section{Control variables}

Market-supporting institutions may become stronger over time because of cumulative reforms undertaken with individual privatization transactions (Ramamurti, 2000). Given the institutional development over time, recent privatization projects may be less likely to fail. There is a possibility that newly privatized projects, although still under construction now, might have problems in the future given enough time of observation. Since we can only observe the status of projects till 2009, there might be a failure bias towards earlier privatized projects. It is also possible that new technologies arise over time that lower the transaction costs present in markets (David \& Han, 2004). We control for the year lapsed (age) from when the projects were set up till 2009 to reduce this problem.

Other control variables include payment to the government (payment), physical assets invested (assets), and the time between project closure and project commitment (delay). Dummy variables are included to indicate whether or not the projects are supported by a bank (bank) and are publicly traded (public). Four primary sectors of infrastructure-namely, transport, energy, telecommunication, and water and sewerage sectors - are controlled. We also control six geographic areas: (1) East Asia and Pacific, (2) Europe and Central Asia, (3) Latin America and the Caribbean, (4) Middle East and North Africa, (5) South Asia, and (6) Sub-Saharan Africa.

\section{Analysis techniques}

Management scholars often wish to examine the advantage of a strategy compared to alternatives to assist managers with their strategic decision-making. However, a difficulty in drawing such conclusions is that firms purposely choose their strategies based on their capabilities and environmental conditions (Shaver, 1998). A private entity's choice of publicprivate partnership is based on its assessment of the environment and the characteristics of the privatization project. In other words, private entities self-select the strategies we observe, and the strategies are endogenous to the expected performance outcomes. Empirical estimates of the performance of a strategic decision that do not correct for this problem may be misleading (Masten, 1993).

To overcome this problem, we use a switching regression model, in labor economics switching refers to individuals switching sectors, such as union vs non-union jobs. (Hamilton \& 
Nickerson, 2003; Heckman, 1974; Shaver, 1998). We estimate this model in two steps. First, we estimate a multinomial logit model to predict the choice of public-private partnership form and construct the inverse Mills ratio terms. It is difficult in many management data sets to find instrumental variables that affect strategic choice but not performance (Hamilton \& Nickerson, 2003). We use payments to the government as an instrument since payments to the government is likely to affect the form of public-private partnership but is unlikely to directly affect project survival. In the second step, we estimate the survival of the public-private partnership projects via probit models, including the inverse Mills ratio to obtain unbiased estimates of coefficients.

\section{Findings}

Table 1 summarizes the variables, and Table 2 reports the results of first-stage multinomial model. The base category in Table 2 is greenfield, so that the coefficients are interpreted as affecting the odds of choosing management contract or acquisition, relative to the odds of choosing greenfield form. We find that a privatization project in a politically more stabile country favors management contract over acquisition and greenfield, supporting Hypothesis 1a. Foreign investors tend to invest in acquisition projects, supporting Hypothesis $2 \mathrm{a}$. Hypothesis $3 \mathrm{a}$ is also supported. A higher level of private participation is associated with the tendency of choosing greenfield projects.

The results of second stage switching regression model are presented in Table 3 . We regress the survival of the privatized projects on political stability, foreign investors, and the level of private participation along with other control variables. The switching regression model is estimated respectively in each sub sample of public-private partnership form.

To test Hypothesis $1 \mathrm{~b}$, we compare the coefficients of political stability across the column models for three different governance forms. The coefficient for political stability is positive and significant in management contract projects but not different from zero at $5 \%$ level in acquisition or greenfield projects. This means political stability has more favorable effects on the survival of management contract projects than on the survival of acquisition or greenfield projects, supporting Hypothesis $1 \mathrm{~b}$. We did not find the coefficient for foreign investors significant in acquisition projects. Thus, Hypothesis $2 \mathrm{~b}$ is not supported. To test Hypothesis $3 \mathrm{~b}$, we compare the coefficients of the level of private participation across the column models for three different public-private partnerships. We find the coefficient for the level of private participation positive and significant in greenfield projects, but negative in management contract and not significant in acquisition projects. This result indicates that higher level of private participation has more favorable effects on the survival of greenfield projects than on the survival of management contract or acquisition projects, supporting Hypothesis $3 \mathrm{~b}$. 


\section{Table 1}

Descriptive statistics

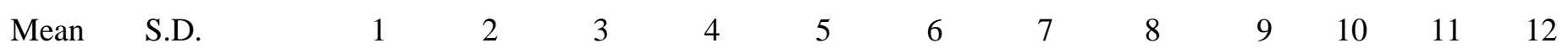

\begin{tabular}{|c|c|c|c|c|c|c|c|c|c|c|c|c|c|}
\hline 1 Performance & 0.93 & 0.23 & & & & & & & & & & & \\
\hline 2 Management & 0.24 & 0.43 & -0.14 & & & & & & & & & & \\
\hline 3 Acquisition & 0.16 & 0.37 & -0.02 & -0.25 & & & & & & & & & \\
\hline 4 Greenfield & 0.59 & 0.411 & 0.14 & -0.63 & -0.59 & & & & & & & & \\
\hline 5 Political stability & 0.32 & 0.24 & -0.05 & 0.22 & -0.06 & -0.14 & & & & & & & \\
\hline 6 Foreign & 0.54 & 0.50 & -0.03 & -0.16 & 0.15 & 0.03 & -0.02 & & & & & & \\
\hline $\begin{array}{l}7 \text { Level of private } \\
\text { ownership }\end{array}$ & 87.17 & 20.76 & 0.01 & 0.07 & -0.39 & 0.25 & 0.21 & -0.10 & & & & & \\
\hline 8 Payment & 3.29 & 0.388 & 0.02 & 0.01 & 0.16 & -0.14 & 0.03 & 0.02 & -0.12 & & & & \\
\hline 9 Asset & 126.48 & 280.61 & -0.001 & -0.06 & 0.01 & 0.04 & 0.08 & -0.06 & 0.05 & 0.09 & & & \\
\hline 10 Age & 11.33 & 4.75 & -0.15 & -0.06 & 0.12 & -0.05 & 0.10 & 0.05 & -0.08 & -0.05 & -0.05 & & \\
\hline 11 Delay & 3.81 & 4.53 & -0.001 & -0.13 & 0.09 & 0.04 & 0.08 & 0.12 & 0.05 & -0.09 & 0.02 & 0.48 & \\
\hline 12 Public & 0.11 & 0.32 & 0.02 & -0.11 & 0.32 & -0.17 & 0.06 & -0.06 & -0.15 & 0.15 & 0.17 & 0.21 & 0.21 \\
\hline 13 Bank support & 0.22 & 0.41 & -0.05 & -0.02 & 0.03 & -0.01 & 0.09 & 0.17 & 0.08 & 0.01 & 0.08 & 0.13 & 0.14 \\
\hline
\end{tabular}


OPTIMAL FORMS OF PUBLIC-PRIVATE PARTERNSHIPS?

\section{Table 2}

Multinomial logit regression of public-private partnership

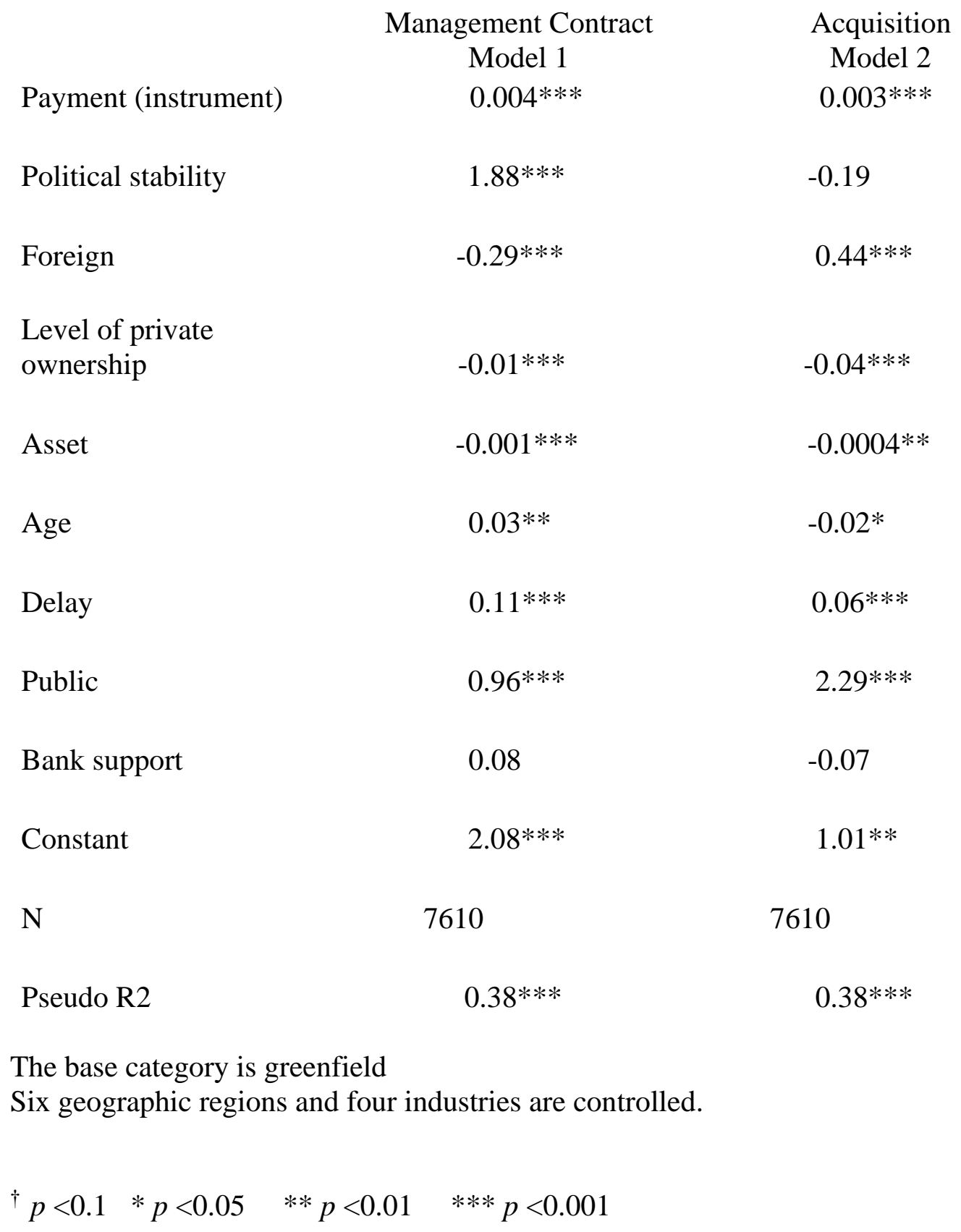


OPTIMAL FORMS OF PUBLIC-PRIVATE PARTERNSHIPS?

\section{Table 3}

Survival of public-private partnerships

\begin{tabular}{|c|c|c|c|}
\hline Political stability & $\begin{array}{c}\text { Model } 3 \\
\text { Management Contract } \\
0.92^{* *}\end{array}$ & $\begin{array}{l}\text { Model } 4 \\
\text { Acquisition } \\
0.30\end{array}$ & $\begin{array}{l}\text { Model } 5 \\
\text { greenfield } \\
-0.28\end{array}$ \\
\hline Foreign & $-0.26 * *$ & -0.40 & -0.05 \\
\hline $\begin{array}{l}\text { Level of private } \\
\text { participation }\end{array}$ & $-0.01 * * *$ & -0.10 & $0.01^{*}$ \\
\hline Asset & $-0.003^{\dagger}$ & $0.003^{* *}$ & -0.00 \\
\hline Age & $-0.15 * * *$ & $-0.11 * * *$ & $-0.13 * * *$ \\
\hline Delay & $-0.03 *$ & $0.03^{*}$ & $0.09 * * *$ \\
\hline Public & $0.37 *$ & $0.83^{*}$ & $1.35^{* *}$ \\
\hline Bank support & $-0.39 * * *$ & 0.11 & 0.02 \\
\hline Constant & $4.15^{* * * *}$ & 13.35 & $2.19 * * *$ \\
\hline $\begin{array}{l}\text { Correction for self- } \\
\text { selection }\end{array}$ & $-0.76^{*}$ & 0.07 & $-0.04 *$ \\
\hline $\mathrm{N}$ & 1848 & 1246 & 4516 \\
\hline Pseudo R2 & $0.25^{* * *}$ & 0.18 & $0.18 * * *$ \\
\hline
\end{tabular}

Six geographic regions and four industries are controlled.

${ }^{\dagger} p<0.1 \quad * p<0.05 \quad * * p<0.01 \quad * * * p<0.001$

\section{Robustness tests}

In Table 2, we find that the instrumental variable - payments to the government—are significant in Model 1 and Model 2, indicating that it affects public-private partnership forms. The inverse Mills ratio is generated in the first stage multinomial logit model and included in the second stage probit models to correct for the self-selection bias. In Table 3, we find that the included inverse Mills ratio in Model 3 and Model 5 are significant, indicating that the estimates of coefficients in the models are corrected for bias. White's robust test is used in both the first stage and second stage models to correct heteroskedasticity. 


\section{Discussion}

In this study, we find evidence that different forms of public-private partnership vary systematically in their governance structures to respond in a coordinative manner to political uncertainty in the institutional environments and to private entities' characteristics. We integrate TCE, agency theory and institution-based view to explain private entities' choices of publicprivate partnership forms and outcomes of such choices.

This study contributes to the literature by linking internal governance structures with attributes of external institutional environments and characteristics of investors in privatization projects. Three major findings can be drawn from our study. First, we find that management contract is the optimal public-private partnership in an institutional environment with more politically stable environment, which contributes to the survival of privatization project. Second, foreign investors favor acquisition in a privatization project, a governance structure with some transactions with the SOE. Third, a higher level of private participation tends to be associated with greenfield, a governance structure with least transactions with the SOE, which then contributes to the survival of the project. We did not find that foreign investors, compared with domestic investors, contribute more to the survival of acquisition projects, a form favored by foreign investors. One possible explanation is that foreign investors use acquisition to gain knowledge and assets in the host country only to make up the disadvantage they have facing domestic competitors. Another explanation is that foreign investors may contribute to the performance of acquisition projects, which cannot be measured by survival in this study.

The findings may have implications for private entities to choose the partnership form and the governance structure in public-private partnership projects based on attributes of external institutional contexts and internal ownership characteristics. Private entities may gain control in privatization through various self-selected governance structures. Following Rediker and Seth's (1995) proposition that firm performance depends on the efficiency of a bundle of governance mechanisms, our findings suggest that external control mechanism may substitute for internal mechanisms in contributing to the quality of corporate governance. An institutional setting with political stability requires less internal control mechanisms to formulate and execute strategies, because the bundle of external and internal governance mechanisms is still efficient to keep firm values. The empirical evidence suggests that the self-selected public-private partnership form may account for the success or demise of public-private partnerships.

\section{Conclusion}

The success of public-private partnership depends on effectiveness of internal and external corporate governance mechanisms. There are optimal forms of public-private partnership depending on the internal ownership structure and the external political stability. Three contributions emerge in this study. First, we extend TCE beyond its usual consideration of private parties. We focus on various levels of transactions between private entities and SOEs and apply them to a spectrum of organizational forms in public-private partnerships. We suggest that the private entities differ from SOEs in their capacity to align actions and self-select the governance structure that better facilitates transactions with SOEs. 
Second, prior research on privatization does not recognize different forms of publicprivate partnership (Zahra et al., 2000). We recognize different governance structures in privatization with respect to different principal-agent relations, and the change of ownership and control. We link principals' and agents' incentives of deciding on the firm's strategic goals and resource allocation with the performance of public-private partnerships.

Third, research suggested viewing governance structures as factors related to organization and institution-level characteristics (Aguilera et al., 2008; Filatotchev et al., 2008; Hoskisson, Hitt, Johnson, \& Grossman, 2002; Meyer \& Peng, 2016). We explore the interdependence of governance structures with characteristics of private entities and institutional environments in the privatization setting. Our findings suggest that optimal public-private partnerships vary depending on the external governance mechanisms and internal transactions between private entities and SOEs. We propose that certain form of public-private partnerships need to be configured to increase performance of privatization projects. Our findings provide guidance to the governments in emerging economies: in politically more stable countries, governments should form managerial contracts with private entities to privatize public businesses; whereas in politically less stable countries, governments should use acquisition and greenfield investments for privatization. When there is a high level of private participation, greenfield investment is the best method of privatization.

Overall, our study contributes to the understanding of governance structures of privatization projects by assessing different forms of public-private partnerships and exploring performances of these forms. Future research that tracks the performance of privatized projects is needed to further develop the model to help governments and private entities make their investment decisions. Our findings reject a "one size fits all" approach to governance structures (Aguilera et al., 2008) in privatization projects by suggesting various optimal forms of publicprivate partnerships and provide a timely guide to privatization process in emerging economies.

\section{References}

Aguilera, R. V., Filatotchev, I., Gospel, H., \& Jackson, G. (2008). An organizational approach to comparative corporate governance: Costs, contingencies, and complementarities. Organization Science, 19(3), 475-492.

Aguilera, R. V., \& Jackson, G. (2003). The cross-national diversity of corporate governance: Dimensions and determinants. Academy of Management Review, 28(3), 447-465.

Aguilera, R., Desender, K., Bednar, M. K., \& Lee, J. H. (2015). Connecting the dots: Bringing external corporate governance into the corporate governance puzzle. Academy of Management Annals, 9(1): 483-573.

Banalieva, E. (2014). Embracing the second best? Synchronization of reform speed, excess high discretion risk, and performance of transition economy firm. Global Strategy Journal, 4(2), 104-126.

Bortolotti, B., \& Faccio, M. (2009). Government control of private firms. Review of Financial Studies, 22, 2907-2939. 
Boubakri, N., Cosset, J. C., \& Guedhami, O. (2005). Postprivatization corporate governance: The role of ownership structure and investor protection. Journal of Financial Economics, 76, 369-399.

Boycko, M., Shleifer, A., \& Vishny, R. (1996). A theory of privatization. The Economics Journal, 106, 309-319.

Bruton, G. D., Peng, M. W., Ahlstrom, D., Stan, C., \& Xu, K. (2015). State-owned enterprises around the world as hybrid organizations. Academy of Management Perspectives, 29(1): 92-114.

Cuervo-Cazurra, Alvaro; Inkpen, Andrew; Musacchio, Aldo; \& Ramaswamy, Kannan. (2014) Governments as owners: State-owned multinational companies. Journal of International Business Studeis, 45, 919-942.

Cull, R., Matesova, J., \& Shirley, M. (2002). Ownership and the temptation to loot: evidence from privatized firms in the Czech Republic. Journal of Comparative Economics, 30, 124.

David, R., \& Han, S.-K. (2004). A systematic assessment of the empirical support for transaction cost economics. Strategic Management Journal, 25, 39-58.

De Castro, J. O., \& Uhlenbruck, K. (1997). Characteristics of privatization: Evidence from developed, less-developed and former communist countries. Journal of International Business Studies, 28, 123-143.

Djankov, S. (2014). The microeconomics of post-communist transformation. In A. Aslund, \& S. Djankov, (Eds.), The Great Rebirth: Lessons from the Victory of Capitalism over Communism, 187-204, Washington, DC: Peterson Institute for Interanational Economics.

Doh, J. P. (2000). Entrepreneurial privatization strategies. Academy of Management Review, 25 , 551-571.

Doh, J. P., Teegen, H., \& Mudambi, R. (2004). Balancing private and state ownership in emerging markets' telecommunications infrastructure: country, industry, and firm influences. Journal of International Business Studies, 35, 232-250.

Dyck, A. (2001). Privatization and corporate governance: principles, evidence, and future challenges. The World Bank Research Observer, 16, 59-84.

Dyck, A., \& Zingales, L. (2004). Private benefits of control: An international comparison. Journal of Finance, 59(2), 537-600.

Filatotchev, I., Stephan, J., \& Jindra, B. (2008). Ownership structure, strategic controls and export intensity of foreign-invested firms in transition economies. Journal of International Business Studies, 39(7), 1133-1148.

Gulati, R., Lawrence, P. R., \& Puranam, P. (2005). Adaptation in vertical relationships: beyond incentive conflict. Strategic Management Journal, 26, 415-440.

Hamilton, B. A., \& Nickerson, J. A. (2003). Correcting for endogeneity in strategic management research. Strategic Organization, 1(1), 51-78.

Heckman, J. (1974). Shadow prices, market wages, and labor supply. Econometrica, 42, 679694.

Henisz, W. J., \& Zelner, B. A. (2001). The institution environment for telecommunications investment. Journal of Economics \& Management Strategy, 10(1), 123-147.

Henisz, W. J., Zelner, B. A., \& Guillen, M. (2005). The worldwide diffusion of market-oriented infrastructure reform, 1977-1999. American sociological Review, 70(6), 871-897. 
Hitt, M., Dacin, M. T., Levitas, E., Arregle, J. L., \& Borza, A. (2000). Partner selection in emerging and developed market contexts: Resource-based and organizational learning perspectives. Academy of Management Journal, 43, 449-467.

Hoskisson, R. E., Eden, L., Lau, C. M., \& Wright, M. (2000). Strategizing in emerging economies. Academy of Management Journal, 43, 249-267.

Hoskisson, R. E., Hitt, M. A., Johnson, R. A., \& Grossman, W. (2002). Conflicting voices: The effects of institutional ownership heterogeneity and internal governance on corporate innovation strategies Academy of Management Journal, 45(4), 697-716.

Jensen, M. C., \& Meckling, W. F. (1976). Theory of the firm: Managerial behavior, agency costs, and ownership structure. Journal of Financial Economics, 3, 305-360.

Jiang, Y., Peng, M. W., Yang, X., \& Mutlu, C. C. 2015. Privatization, governance, and survival: MNE investments in private participation projects in emerging economies. Journal of World Business, 50(2), 294-301.

Johnson, G., Smith, S., \& Coding, B. (2000). Microprocesses of institutional changes in the context of privatization. Academy of Management Review, 25(3), 572-580.

Kalodimos, J. (2017). Internal governance and performance: Evidence from when external discipline is weak. Journal of Corporate Finance, 43, 193-216.

Kogut, B., \& Zander, U. (1993). Knowledge of the firm and the evolutionary theory of the multinational corporation. Journal of International Business Studies, 24(4), 625-645.

La Porta, R., \& Lopez-de-Silanes, F. (1999). The benefits of privatization: Evidence from Mexico. The Quarterly Journal of Economics, 114, 1193-1242.

La Porta, R., Lopez-de-Silanes, F., Shleifer, A., \& Vishny, R. W. (1998). Law and finance. Journal of Political Economy, 106(6), 1113-1155.

Lebedev, S., Peng, M. W., Xie, E., \& Stevens, C. E. (2015). Mergers and acquisitions in and out of emerging economies. Journal of World Business, 50(4), 651-662.

Lin, X., \& Germain, R. (2003). Organizational structure, context, customer orientation and performance: Lessons from Chinese state-owned enterprises. Strategic Management Journal, 24(11), 1131-1151.

Mahoney, J. T. (1992). The choice of organizational form: Vertical financial ownership versus other methods of vertical integration. Strategic Management Journal, 13(8), 559-584.

Makhija, M. (2004). The value of restructuring in emerging economies: The case of the Czech Republic. Strategic Management Journal, 25, 243-267.

Martinez, R. J., \& Dacin, M. T. (1999). Efficiency motives and normative logic: Combining transaction costs and institutional logic. Journal of Management, 25(75-95).

Masten, S. E. (1993). Transaction costs, mistakes, and performance: Assessing the importance of governance. Managerial and Decision Economics, 14, 119-129.

Megginson, W. L., Nash, R. C., Netter, J. M., \& Poulsen, A. B. (2004). The choice of private versus public capital markets: evidence from privatizations. [Article]. Journal of Finance, 59(6), 2835-2870.

Meyer, K. E., Estrin, S., Bhaumik, S., \& Peng, M. W. (2009). Institutions, resources, and entry strategies in emerging economies. Strategic Management Journal, 30(1), 61-80.

Meyer, K. E., \& Peng, M. W. (2016). Theoretical foundations of emerging economy business research. Journal of International Business Studies, 47(1), 3-22.

North, D. C. (1990). Institutions, institutional change, and economic preference. New York: Norton. 
OPTIMAL FORMS OF PUBLIC-PRIVATE PARTERNSHIPS?

Peng, M. W., \& Jiang, Y. (2005). Entrepreneurial strategies during institutional transitions. In L. A. Keister (Ed.), Research in the Sociology of Work (Vol. 15, pp. 311-325). Greenwich, CT: JAI/Elsevier Press.

Peng, M. W., Wang, D., \& Jiang, Y. (2008). An institution-based view of international business strategy: A focus on emerging economies. Journal of International Business Studies, 39, 920-936.

Perotti, E. G., \& van Oijen, P. (2001). Privatization, market development, and political risk in emerging economies. Journal of International Money and Finance, 20, 43-69.

Poitevin, M. (1995). Contract renegotiation and organizational design. CIRANO Working Papers 95s-03, CIRANO.

Ramamurti, R. (2000). A multilevel model of privatization in emerging economies. Academy of Management Review, 25, 525-550.

Ramamurti, R. (2003). Can governments make credible promises? Journal of International Management, 9, 253-269.

Rediker, K. J., \& Seth, A. (1995). Boards of directors and substitution effects of alternative governance mechanisms. Strategic Management Journal, 16(2), 85-99.

Shaver, J. M. (1998). Accounting for endogeneity when assessing strategy performance: Does entry mode choice affect FDI survival? Management Science, 44(4), 571-585.

Shin, D. (2017). Optimal loyalty-based management. Journal of Economics and Management Strategy, 26(2), 429-453.

Shleifer, A., \& Vishny, R. W. (1994). The politics of market socialism. Journal of Economic Perspectives, 8(2), 165-176.

Spicer, A., McDermott, G. A., \& Kogut, B. (2000). Entrepreneurship and privatization in central Europe. Academy of Management Review, 25, 630-649.

Walsh, J. P., \& Seward, J. K. (1990). On the efficiency of internal and external corporate control mechanisms. Academy of Management Review, 15(3), 421-458.

Williamson, O. E. (1985). The economic institutions of capitalism: Free Press: New York.

Williamson, O. E. (1991). Comparative Economic Organization: The Analysis of Discrete Structural Alternatives. Administrative Science Quarterly, 36(2), 269-296.

Williamson, O. E., \& Ouchi, W. G. (1981). The markets and hierarchies program of research: Origins, implications, and prospects. In A. H. Van de Yen \& W. F. Joyce (Eds.), Perspectives on organization design and behavior (pp. 347-370). New York: WileyInterscience.

Wright, M., Filatotchev, I., Hoskisson, R. E., \& Peng, M. W. (2005). Strategy research in emerging economies: Challenging the conventional wisdom. Journal of Management Studies, 42(1), 1-33.

Zahra, S. A., Ireland, H. D., Gutierrez, I., \& Hitt, M. A. (2000). Privatization and entrepreneurial transformation: Emerging issues and a future research agenda. Academy of Management Review, 25, 509-524. 